\title{
2: 70053968-70077256
}

National Cancer Institute

\section{Source}

National Cancer Institute. 2: 70053968-70077256. NCI Thesaurus. Code C45086.

Physical location of MAD_Gene 